\title{
RADICALIZING INDONESIAN MODERATE ISLAM FROM WITHIN The NU-FPI Relationship in Bangkalan, Madura
}

\author{
Ahmad Zainul Hamdi \\ IAIN Sunan Ampel, Surabaya - Indonesia
}

\begin{abstract}
This article tries to present the most current phenomenon of how moderate Islam can live side by side with radical Islam. By focusing its analysis on the dynamics of political life in Bangkalan, Madura, the paper argues that the encounter between these two different ideological streams is possible under particular circumstances. First, there is a specific political situation where the moderate Islam is able to control the political posts. Second, there is a forum where they can articulate Islamic ideas in terms of classical and modern political movements. This study has also found out that the binary perspective applied in the analysis of Islamic movement is not always relevant. The fact, as in the case of Bangkalan, is far more complex, in which NU and Islamic Defender Front (FPI) can merge. This is so because at the beginning, FPI's management in the city is led by kyais or/and prominent local NU leaders.
\end{abstract}

Keywords: Radicalization, de-radicalization, moderate Islam, radical Islam.

\section{Introduction}

A discussion on the topic of contemporary Islamic movements is filled with various reviews about radical Islam. As news, academic work also has its own actual considerations. The September $11^{\text {th }}$ incident seems to be a "productive" momentum to tap a new academic debate which was previously conducted only by a few people who were really making Islam and its socio-political life as an academic project. Islamism, in its violence and atrocity, then became a popular theme that filled almost all the scientific discussion that took ideology and contemporary Islamic movements as a main topic. This 
multiplication theme was reinforced by the project of "War on Terror" that was designed to define a scheme of new relationship between Islam and the West.

It is nothing new that any political project that involves a relationship between two civilizations is often accompanied by various academic projects. Orientalism, for instance, apart from the development and critical attitude that come from within, is the academic project that is directly linked to imperialism at first. ${ }^{1}$ In fact, anthropology is not immune from these imperialistic "sins."2

To mark the study of radical Islam as a trending topic today, constantly emerging perspective is the use of binary oppositions: moderate versus radical, ${ }^{3}$ puritan versus pluralism, ${ }^{4}$ democrat versus Islamist, ${ }^{5}$ liberal versus conservative, ${ }^{6}$ and some other binary

1 Edward Said's writings remain the most representative sources in viewing the relationship between Orientalism and imperialism. Orientalism, at least, at the beginning of its age, was a way of how the West looked at the East-Islam which was characterized by superior-inferior, civilized-uncivilized, high-low. See Edward Said, Orientalism (New York: Vintage, 1979).

2 Koentjaraningrat, Pengantar Ilmu Antropologi (Jakarta: Rineka Cipta, 2009), pp. 3-4.

3 Stephen Sulaiman Schwartz, Dua Wajah Islam: Moderatisme vs Fundamentalisme dalam Wacana Global, translated by Hodri Ariev (Jakarta: Libforall, Blantika, The Wahid Institute, Center for Islamic Pluralism, 2007).

${ }^{4}$ Khaled Abou El Fadl, Cita dan Fakta Toleransi Islam: Puritanisme versus Pluralisme, translated by Heru Prasetia (Bandung: Throne, 2003). This book is actually a collection of papers written by Khaled Abou el-Fadl and many other intellectuals who respond the latter's ideas. Its contents speak about the two currents of Islamic thought and movement in viewing tolerance and relationship between Islam and the West. This book was originally entitled The Place of Tolerance in Islam, which later changed its title into Indonesian language as above because it reflects the dispute between the puritanists and the pluralists.

5 Robert W. Hefner, "Muslim Democrats and Islamist Violence in Post-Soeharto Indonesia," in Robert W. Hefner (ed.), Remaking Muslim Politics: Pluralism, Contestation, Democratization (Princeton, New Jersey: Princeton University Press, 2005).

${ }^{6}$ Caryle Murphy, Passion for Islam: Shaping the Modern Middle East: The Egyptian Experience (New York: Scribner, 2002); Virginia Hooker, "Developing Islamic Arguments for Changing through Liberal Islam," in Virginia Hooker and Amin Saikal (eds), Islamic Perspectives on the New Millenium (Singapore: ISEAS, 2004); Leonard Binder, Islam Liberal: Kritik Terbadap Ideologi-Ideologi Pembangunan, translated by Imam Muttaqin (Yogyakarta: Pustaka Pelajar, 2001); Rumadi, Post Tradisionalisme Islam: Wacana Intelektualisme dalam Komunitas NU (Jakarta: DEPAG RI, 2007). 
categories. ${ }^{7}$ In such a frame of mind, Islam is seen as blocks of community, school of thought, method of movement, and isolative school of teaching.

This is not to say that scientific analysis should not be doing categorization. However, the category that originated from an academic research to see variations in the community is often treated as real spaces where occupants are isolated from each other. ${ }^{8}$ What is going to dealt with in this paper is to open a new perspective that is no longer strictly burdened by binary category of moderate Islam versus radical Islam. There are meeting rooms between the two, which may not be permanent, but there are also moments of tension in certain cases. All these phenomena become so complex that it is not likely enough to be portrayed with too tight and stiff approach employing a binary category.

Reductive risk of way of thinking in terms of binary opposition and absolute categories of moderate Islam versus radical Islam in contemporary Indonesia may be easily seen when we are dealing with a case of the following: on February 22nd, 2011, PWNU (Pengurus Wilayah Nahdlatul Ulama/Provincial Branch of Nahdlatul Ulama) of East Java held a seminar at Hotel Bumi Surabaya in commemoration of

\footnotetext{
${ }^{7}$ See, M. Imdadun Rahmat, Arus Baru Islam Radikal: Transmisi Revivalisme Islam Timur Tengah ke Indonesia (Jakarta: Erlangga, 2005); Norani Othman (ed.), Muslim Women and The Challenge of Islamic Extremism (Selangor: Sister in Islam, 2005); Thoha Hamim, Islam \& NU di Bawah Tekanan Problematika Kontemporer (Surabaya: Diantama, 2004), within the sub-title: "Islam Militan versus Islam Moderat: Perilaku Politik Kaum Islam Militan di Masa Pemerintahan Presiden KH Abdurrahman Wahid"; some other works discuss the radical Islam movement, which is explicitly in opposition to the moderate Islam. Read Itzchak Weismann, "Sa'id Hawwa: The Making of Radical Muslim Thinker in Modern Syria," in Syafiq Mughni (ed.), An Anthology of Contemporary Middle Eastern History (Montreal: Indonesia-Canada Islamic Higher Education Project, n.d.); Jamhari and Jajang Jahroni (eds), Gerakan Salafi Radikal di Indonesia (Jakarta: PT Raja Grafindo Persada, 2004).

${ }^{8}$ Critics of this reasoning are advanced by Beatty on categorization made by Geertz on Javanese Islamic character. According to him, Geetz's theoretical framework in making such category as santri, abangan, and priayi is being outrageous and exaggerated when he delineated and treated it as tight spaces and unbridgeable distance among the three. As if, a category was the iron prison which was not possible for each category to negotiate and interpenetrate with the equal degree of activity and consciousness. See Andrew Beatty, Variasi Agama di Jawa: Suatu Pendekatan Antropologi, translated by Achmad Fedyani Saefuddin (Jakarta: Murai Kencana, 2001); See also Harsya W. Bachtiar, "The Religion of Java: A Commentary Review," in Clifford Geertz, Abangan, Santri, Priyayi (Jakarta: Pustaka Jaya, 1983).
} 
the $88^{\text {th }}$ birthday of NU (Nahdlatul Ulama). ${ }^{9}$ It was nothing special as the anniversary of NU is yearly celebrated. That seemed unusual was the presence of the leading leaders of FPI (Front Pembela Islam/Islamic Defender Front), Rizieq Shihab and Munarman. The attendance of Rizieq was special because he was invited to be a guest speaker at the seminar. Rizieq was not only honored as a guest, but also recognized as part of NU as stated by Hasyim Muzadi in his speech that "Habib Rizieq is NU and he often said that he was NU." In fact, Muzadi provided a defense in order that FPI was not dissolved. ${ }^{10}$

NU is known as a moderate Islamic organization, where its moderation is often contrasted with the usual violence carried out by radical Islamic groups. Meanwhile, FPI is commonly known as the Islamist group who likes to do violence. Such a definition of moderation is often stated by NU leaders who look FPI differently from NU. NU represents moderate Islam, while FPI is radical Islam. But at the time, the number one person of FPI was invited as a guest speaker to discuss the vision of his Islam and was recognized as part of NU.

It was indeed a very strange scene. The moderation of NU seemed to melt and fuse into the FPI's violent face. There was no longer restriction or at least, it became increasingly blurred. If everyone was so easy to hear the difference between the moderation of NU and the radicalism of FPI from NU leaders previously, the forum seemed to erase the distinction. FPI has now become a part of NU. At least, one might have thought that the violent character of FPI can also be a part of the Islamic movement of NU, or, the moderateness of NU could become part of the radical movement of FPI.

This phenomenon, of course, has spawned a lot of confusion and questions. This is reflected in the writing of an activist of NU in Yogyakarta who has been proud of NU's moderation for being able to be a barrier to the dissemination of radical Islamist movements. He wrote that:

...apparently, FPI and NU now start to meet. Some time ago, FPI's chairman, Rizieq Sihab was invited/present in gathering with $\mathrm{KH}$. Hasyim Muzadi (as well as the other

\footnotetext{
${ }^{9}$ http://www.tempointeraktif.com, accessed on March 22 ${ }^{\text {nd }}, 2011$.

${ }^{10}$ http:// nasional.vivanews.com, accessed on March 23 $3^{\text {rd }}, 2011$.
} 
speakers) in the harlah of NU at PWNU East Java. Even, in the forum, the moderator called Rizieq as the representation of radical NU. What the indication is this ...? ?11 $^{11}$

The book Ilusi Negara Islam (Illusion of an Islamic State) sees this phenomenon as the Islamist infiltration into the institutions or organizations that Islam is known as a moderate character. Both of NU and Muhammadiyah are surely the target of such infiltration. Extremists do not only infiltrate into NU and Muhammadiyah, but also "take over" the mosques and schools, even they go to pesantrens (Islamic boarding schools). ${ }^{12}$

However, the presence of Rizieq Shihab in an important event of PWNU East Java did not confirm the existence of these intrusions. Infiltration presumes an unequal position, with one is active and another one is passive. However, what happened in that event did not indicate the passivity of one of the parties, unless NU looked so "stupid" that falls into the trap set by such a shrewd one like Shihab.

This paper highlights the latest development of the Islamic movement in Indonesia. As stated by Bubalo and Fealy, ${ }^{13}$ a growth of radical Islamic movements in Indonesia is largely derived from the outside, but Indonesia itself is a ground for seeding dawn every doctrine and Islamic movements. Whatever sticks planted on the ground, it would become a fruitful tree. This means that Indonesian Islam provides a very open and a very broad opportunity for any doctrine to come and influence each other. In this dialectical situation, the discrete concept of moderate versus radical Islam needs to be tested again.

The encounter between NU and FPI is not unknowingly presented because they directly represent the two concepts: moderate versus radical Islam. NU is known as a moderate Islamic organization. NU's moderation was born from the Islamic thought typical to the traditionalists. One of the basic characters of NU is its tolerance to various local traditions, a fundamentally different attitude to the

11 Posted by Ahmad Shidqi, bahtsulmasail-nu@yahoogroups.com, accessed on February 27th, 2011.

12 Abdurrahman Wahid (ed.), Ilusi Negara Islam: Ekspansi Gerakan Islam Transnasional di Indonesia (Jakarta: The Wahid Institute, Gerakan Bhinneka Tunggal Ika, Maarif Institute, 2009).

13 Anthony Bubalo and Greg Fealy, Joining the Caravan? The Middle East, Islamism and Indonesia (Alexandria: Lowy Institute for International Policy, 2005). 
puritan who is very obsessive with pure Islam, which make him lose an appreciation and tolerance of the local culture. Appreciation to the tradition, either classical or local, could be called the inner spirit of the organization founded by Hasyim Asy'ari in Surabaya in 1926.14

Bangkalan, Madura is chosen as the region to see the new direction of the Islamic movement in Indonesia. Lifting Madura in the discussion of NU is like sorting the sugar out of its sweetness. The identity of NU-Madura is an Islamic society itself. Some experts associate this phenomenon with pesantrens that have been the main base of NU. As a typical of Islamic educational institutions, Islamic boarding schools are very closely tied to the culture of Java and Madura. As a result, one should not be surprised if they grow and thrive in this region. That is why NU becomes a religio-cultural identity of the Madurese in general. ${ }^{15}$

\section{Bangkalan and NU}

Bangkalan is one of the four districts in Madura. This district is the westernmost and connecting Surabaya to Madura island. Before the opening of the longest bridge, Suramadu, in 2009, Kamal, one of the sub-districts in Bangkalan, was a dock where ferries were crossing from Surabaya to Madura or vice versa.

As historical cities in Java began to exist at about the early of the Islamic kingdom of Java, the historiography of Bangkalan also began to be written in this era. Historical records of Bangkalan began in the mid of the $16^{\text {th }}$ century $(1531 \mathrm{AD})$, which was known as "age of

14 Greg Fealy and Virginia Hooker (eds.), Voices of Islam in Southeast Asia: A Contemporary Sourcebook. (Singapore: ISEAS, 2006), p. 40.

${ }^{15}$ Laode Ida, NU Muda: Kaum Progresif dan Sekularisme Baru (Jakarta: Erlangga, 2004), p. 2; The cultural specificities appear such as in obedience, submission, and their surrender hierarchically to the four major figures in their life, moreover in religious praxis: Buppa, Babbu, Guru, and Rato (father, mother, teacher, and leader of the government). To the four major figures, the Madurese's hierarchical compliance shows its form in the social life of their culture. The use and mention of the term Guru refers and emphases on understanding and attention of Kyai-pesantren to religious development in Islamic boarding house. Kyai is the most influential figure for the Madurese. Teacher (kial) is an assurance of morality issues and problems of hereafter. It is understandable that the Madurese's obedience to kyai or teacher is based on those reasons. See A. Latief Wiyata, Carok Konflik Kekerasan dan Harga Diri Orang Madura (Yogyakarta: LKiS, 2006), p. 1. 
sainthood". Inevitably, the history of Bangkalan was closely associated with the history of Islam in Madura island. ${ }^{16}$

In the context of the establishment and development of $\mathrm{NU}$, Bangkalan occupies a key position. The founder of NU, Kyai Hasyim Asy'ari, was the pupil of Kyai Cholil Bangkalan. ${ }^{17}$ When Abdul Wahab Hasbullah proposed his wish to Hasyim Asy'ari to establish an organization that was later called NU, the latter did not confirm until he got a spiritual endorsement from Kyai Cholil Bangkalan. After getting permission from Bangkalan, Hasyim finally made a decision, "Allah has allowed us to establish an organization".18

Up to now, the descendants of Kyai Cholil Bangkalan become kyai who are highly respected by the Muslim community there. They are the role model for Muslims in Bangkalan, even in Madura in general. Pesantren of Syaichona Cholil Bangkalan can be regarded as the site of Islamic reference for Muslims in Madura. This pesantren occupies an important position in the whole movements of Muslim communities in the district. It can be said that this pesantren has been the axis of all Muslims in Bangkalan, the majority of which is NU. All religious, political, and cultural movements that enter into Bangkalan require legitimacy from Kyai Cholil's families if they wish to be accepted by the community there.

\section{FPI Bangkalan: The Melting of Moderatism and Radicalism}

FPI (Islamic Defender Front) was born on August 17th 1998 by the chairperson Muhammad Rizieq Shihab. After it was established in Jakarta, FPI established branches in West Java, Lampung, Palembang, North Sumatra, East Java, Sulawesi, Ambon, Maluku, Tual, and Borneo. It now exists in almost all the provinces of the country.

The history of FPI in Bangkalan, Madura, began in 2004, when Rizieq Shihab gave religious lecture in the sub-district Blega, Bangkalan. ${ }^{19}$ His coming to this district was made possible by the

\footnotetext{
16 http://www.bangkalankab.go.id, accessed on February 3 $3^{\text {rd }}, 2011$.

17 Lathiful Khuluq, "K.H. Hasyim Asy'ari: "Profil Pejuang dari Jombang," in Jajat Burhanudin and Ahmad Baedowi (eds), Transformasi Otoritas Keagamaan: Pengalaman Islam Indonesia (Jakarta: Gramedia, 2003), p. 48.

18 See, Choirul Anam, Pertumbuhan dan Perkembangan NU (Surabaya: Duta Aksara Mulia, 2010).

19 See, Mohammad Tikno Muyono, Dakwah Front Pembela Islam (FPI) di Kabupaten Bangkalan; Studi Kualitatif tentang Gerakan Amar Ma'ruf Nabi Munkar (Unpublished thesis, Dakwah Faculty, IAIN Sunan Ampel Surabaya, 2009).
} 
student of KH. Abdul Munif Pamekasan who was captivated by the views of Rizieq. When he invited Rizieq in Blega, he deliberately invited a great deal of religious and community leaders of Bangkalan.

One of those invited was Nasir Zaini, a prominent businessman who was also influential figure within the local organizations, the Association of Madura Family (IKAMRA) and Madura United Forum (FORMABES). At that moment, there was an informal agreement to establish FPI in Bangkalan. Rizieq asked Nasir Zaini to become the interim coordinator.

Nasir Zaini began to recruit members and approached the community leaders and kyais in that region. One of the important figures who successfully approached was the pesantren's caregiver Syaichona Cholil I, KH Abdullah Schal, tweet of Kyai Cholil Bangkalan. Finally, on September $3^{\text {rd }}$, 2005, when the pesantren held haflat alimtihän wa al-ikbtibär, Rizieq Shihab was invited as a speaker, and it was also attended by some influential kyais in Bangkalan. At that time, it was then performed a limited discussion to formulate the establishment of Regional Leadership Board of the Islamic Defender Front (FPI) in Bangkalan.

Haflat al-imtihan is very crucial for the existence of FPI in Bangkalan in the future. Although the September $5^{\text {th }}, 2005$ is considered as the date of the establishment of the FPI Bangkalan, but haflat al-imtihă an event can be considered as an open declaration of the establishment of FPI in Bangkalan.

At the early time of FPI's management in Bangkalan, the big families of pesantren Syaichona Cholil had occupied a key position. It could be said that the Kademangan family, another term for the descendants of Kyai Cholil, was the controller of FPI Bangkalan. The chairman of the Shura Council was held by K.H. Abdullah Schal, while the chairman of Tanfidz was K.H. Fahrillah Aschal. FPI Bangkalan domiciled and headquartered in the city of Bangkalan, precisely at pesantren of Syaichona Cholil I in Kademangan, Bangkalan.

In this initial period, FPI immediately performed some strikes. Many people claimed that FPI Bangkalan under Fachrillah Aschal had become a highly respected organization as its assertiveness and prowess in combating immorality issues. The presence of FPI in 
Bangkalan was considered to be able to act as a motor in eradicating disobedience. $^{20}$

\section{Pesantren's and NU's Response}

On June 1st, 2008, AKKBB (National Alliance for Freedom of Religion and Belief) held a rally in Monas Jakarta to commemorate the anniversary of Pancasila. The alliance was made up of various institutions and figures that had been concentrated on advocating the right to freedom of religion and belief. The rally, which was designed as a peaceful activity was going to call for Indonesia's bhinneka tunggal ika under Pancasila which was critically endangered by forces that impose their will and did not appreciate diversity.

Such a friendship nuanced activity since involved family members (husband/wife and children) suddenly turned into chaos when the Islamic Army Command (the main element of FPI paramilitary force) attacked and beat up participants of rally. This was one of the open violence committed by FPI to pro-democracy groups.

Immediately, FPI's assault got harsh reactions from various parties. Almost all people condemned the FPI's anarchy. As response to this anarchy, Ansor, youth organization under NU, called on its paramilitary forces (Banser) to fight the FPI's tyranny. ${ }^{21}$ The call was apparently effective. Ansor with its Banser was being part of a wave of protest everywhere condemning and demanding the dissolution of FPI, not least in East Java.

In Banyuwangi, the local Shura Council of FPI, KH Samsul Ma'arif, officially retired from management after pressed by Ansor. In Probolinggo, dozens of mass called as "Defender of Gus Dur" reached the local chairman of FPI, Habib Lutfi. Not just at the eastern of East Java FPI received pressure to be disbanded, in Blitar, a local FPI was also urged to be disbanded by the mass called Defender Front of National Awakening (FPKB).22

Under the pressure to be disbanded, FPI branch Madura refused to disperse. ${ }^{23}$ The FPI's coordinator of Madura region, Bahri Asrawi said: "FPI in Madura has good relation with Banser and Garda Bangsa

\footnotetext{
${ }^{20}$ Interview with Deputy Secretary of PCNU Bangkalan, HM Toyyib Muslim Fawwaz, March 5 $5^{\text {th }}, 2011$.

${ }^{21}$ Banser (Barisan Ansor Serbaguna) is a paramilitary force that is under Ansor.

22 http://www.nuonline.com, Jun 5 th , 2008, accessed on February 3 $3^{\text {rd }}, 2011$.

${ }^{23}$ http://www.detikSurabaya, Jun 4th, 2008, accessed on February 3 $3^{\text {rd }}, 2011$.
} 
(security forces of National Awakening Party), although in other places experiencing tension. ${ }^{24}$

The story of the tension between FPI and NU in 2008 as well as FPI's insistence in Madura not to disband by the reason of a good relationship with NU, tells us something about FPI in Madura. What stated above by Bahri Asrawi is not something ridiculous. The history of FPI's establishment in Bangkalan confirms the truth of the confession. Since its inception, FPI Bangkalan has been handled by pesantren's leaders who are also the prominent leaders of NU. Even in 2008 there was an open tension between the institutions affiliated to NU with FPI, but this was not able to deny the closeness in relationship between NU and FPI.

This closeness can also be seen in the case of the mid-2008. The case stemmed from the report that Bindara Ali, chairman of Istighathah Dhikrullăh Qotbul Ghair, had issued by stating "it is not the sin of fornication, the existence of heaven and hell is a lie, and God is as created beings." These issues came to Islamic Defender Front (FPI), which was then forwarded to the Council of Indonesian 'Ulama' and NU. Following that, the dialogue was held in the office of PCNU Bangkalan which involved MUI, NU, FPI, Laskar Jihad, Kesbang Bangkalan, Bangkalan police, prosecutors, Muspika Klampis, and head village of Bator to clarify the news to Bindara Ali. The parties who presented then concluded that what was said by Bindara Ali was misguided. ${ }^{25}$

The people did not look at the relationship between NU Bangkalan and FPI. In general, the views of NU leaders towards FPI are relatively positive. They cannot surely accept the FPI violence, but they can accept rigorous propaganda and implementation of al-amr bi al-ma'rüf wa al-naby 'an al-munkar (commanding good and forbidding wrong) because it is considered as an accurate way to eliminate immorality in society. NU's figures greatly respect FPI's firmness in implementing the concept of al-amr bi al-ma'rüf wa al-naby 'an al-munkar, something they said could not be done by NU so far.

If they then join the FPI's movement, it means that they do not perform any betrayals of the NU's principles because NU, as an

24 http://www.nuonline.com, Jun 5th, 2008, accessed on February $3^{\text {rd }}$, 2011; http://www.seputarjatim.com, Jun $4^{\text {th }}, 2004$, accessed on February $3^{\text {rd }}, 2011$.

25 http:/ /www.tabloidposmo.com, August 10 ${ }^{\text {th }}, 2006$, accessed on February $3^{\text {rd }}, 2011$. 
Islamic organization, believes that it should do an Islamic propagation (da'wah Islamizab). Da'wah al-Islamiyyah in the sense of al-amr bi al-ma'ruf wa al-nahy 'an al-munkar is also the teaching embraced by NU. So that, principally, no conflict between NU and FPI. Therefore, al-amr bi alma'rü wa al-naby 'an al-munkar implemented by FPI can be accepted by NU. What distinguishes is about the method of implementation of the concept. In this case, NU explicitly rejects violent methods commonly performed by FPI, for example, raiding over cafes, nightclubs and other amusement centre, destroying places of worship of other groups, and attacking groups indicated defaming Islam.

This was in line with the statement made by Deputy Secretary of PCNU Bangkalan, M. Fawwaz Toyyib Muslim:

As a member of NU, I do not agree with anarchy or violence on the name of Islam which frequently committed by those groups. I do not mention who those groups are. But anyway, I do not agree with violence on the name of Islam because Islam is rabmatan li al-älamin. So, if violence is chosen as a way, which one is called Islam as rabmatan li al'alamin? Besides, our country is democracy, so any problem occurs is at the hand of the authorities to settle. We are not allowed to do or judge someone whose thinking is different. ${ }^{26}$

Reason of preventing violence in preaching is also the the reason why NU leaders want to get involved in, even to be a leader of, FPI Bangkalan. NU leaders cannot accept violence on the name of Islam as was done by FPI. So, when FPI entered into Bangkalan, the options were to decline or to domesticate it. Apparently, the latter option was taken. Kyai Fahrillah Aschal agreed to be the chairman of FPI Bangkalan by the reason for not providing opportunities for FPI to do violence in Bangkalan.

Once I asked Kyai Fahri, "Kyai, why do you agree to be the chairman of FPI?" Kyai Fahri said: "If it is not me who hold FPI, this organization will be joined by others who might not be kyais. And it might be held by thugs. If it is they holding the FPI, it might always confront to kyais. So, when it is held by me, I do not think that FPI is radical." He added: "The reason why I (Kyai Fahri) agree to become the

\footnotetext{
${ }^{26}$ Interview with Toyyib Fawwaz Muslim, March 5th 2011.
} 
Chairman of FPI is due to the consideration not to give an opportunity to FPI applying violence in Madura. Thus, when FPI is held by me, there is nothing violent in Bangkalan, because we are favoring more onto dialogue." Well, because the community asked Kyai Fahri to become the Chairman of NU, he released his position in FPI, and it was then handed over to Kyai Khon Tobroni in 2007. ${ }^{27}$

From the above explanation it is obvious that the strategy which is taken by the NU leaders is de-radicalization from within. By looking at the influence of Kyai Fahrillah Aschal, FPI Bangkalan has to think twice in committing violence as happens elsewhere. If such a very influential kyai is willing to do violence, the impact can be highly counterproductive since he has so many adherents. The moderate vision of the two kyais leads to a very minimal use of violence by FPI Bangkalan. In fact, since it was held by Kyai Khon Tobroni, FPI Bangkalan has been idle in terms of its movement.

However, to say that FPI Bangkalan never employs violence is also incorrect. The testimony of several people suggested that FPI Bangkalan has done few sweeping to amusement places, particularly when FPI was under the leadership of Kyai Fahrillah Aschal. T. F. Muslim's statements below illustrate the behavior of FPI under the control of NU's figures.

Well, that's no coincidence that IPNU has commissariat in almost all Islamic boarding schools. So, if there are any actions, they will automatically attend, like sweepings... Because he (Kyai Fahrillah Aschal, The first Chairman of FPI Bangkalan) is a very influential and also has many students and followers. Under his control, FPI was ever large and often appeared to make sweeping in illicit places, such as cafes, nightclubs in the square, and the back of the stadium. ${ }^{28}$

\footnotetext{
${ }^{27}$ Interview with Toyyib Fawwaz Muslim, March 5 ${ }^{\text {th }}, 2011$.

28 Interview with the Branch Chairman of IPNU Bangkalan, M. Wahid, Maret $5^{\text {th }}$, 2011; "Ra Fahrillah, before he became the head of NU, had also been the head of FPI. FPI under the leadership of Ra Fahrillah experienced rapid development, it never performed demonstrations, once moral call was heard by the House of representative in Bangkalan in the public hearing," Said Sonhaji, the Branch Chairman of PMII Bangkalan (Interview, March $\left.4^{\text {th }}, 2011\right)$.
} 
It can be stated here that FPI Bangkalan under the leadership of Kyai Fahrillah Aschal had made several sweepings as the cases of FPI elsewhere. Nevertheless, it was just very controlled action, so they did not do any damaging violence. The absence of an open clash could also be understood since Kyai Fahrillah Aschal had a lot of followers and a very wide influence. Consequently, his movement and action received approval from NU and Muslims in Bangkalan in general.

If one thinks that a positive attitude towards FPI is only among the older generation, he or she could be wrong. The younger generations of NU Bangkalan also have a good assessment of the existence of FPI in Bangkalan. Below is a view of the figures of PMII (Indonesian Islamic Students Movement) Bangkalan, a student organization which is theologically affiliated to NU, and that of the figures of IPNU (NU Student Association), who are directly under NU.

I think FPI Bangkalan is very well so far, and its existence is highly accepted by the community because the majority of people in Bangkalan are the pesantren's students (santr). FPI is very nice and helpful in Bangkalan because it serves as moral control in Bangkalan. In addition, the majority of FPI's figures in Bangkalan are also from the figures of NU like Kyai Badrus Sholeh, the current FPI's Chairman. He is also a prominent leader of NU.... An average Madurese also agree with the FPI's presence here, they are a moral community control. ${ }^{29}$

...I do not agree with violence, but I agree with the presence of FPI here. It is because there must be a stringent Islamic organization like FPI so that people do not violate the rules but they follow the rules.... I personally accept FPI but it should not run an anarchic way. Even, there should be a group and community who support the existence of an organization like FPI. That is not to cause casualties, particularly those who are not guilty. The case of people's misguided belief is their own problem and they should be responsible for themselves. So, FPI should be more dialogical. Meaning, by running dialogue, FPI will not be considered as an anarchist. And the point is that there

${ }^{29}$ Interview with the Branch Chairman of PMII Bangkalan, Sonhaji, March $4^{\text {th }}, 2011$. 
should be FPI in Indonesia because no one dares to do like that. ${ }^{30}$

Taking those statements above into account, what we can see from the background of FPI's coming and growth in Bangkalan is a story of an encounter of the two entities that had been considered impossible to meet. Since the beginning, FPI was very closely hand in hand with local leaders of NU. Holding local figures of NU is an accurate strategy that cannot be ignored if FPI wants to exist and thrive in Bangkalan. This strategy proves to have succeeded so far.

The entire terrace leaders of FPI Bangkalan are very influential kyais of NU Bangkalan. They are the leaders of pesantren (Islamic boarding school) that have hundreds, even thousands of students as well as the devout followers in community. Not surprisingly, it can be said that the FPI's members are the students and the people who have claimed themselves as NU followers and who have great obedience to kyais. Most of the people accept and view positively the existence of FPI. Moderate Islam and radical Islam thus have met. As quoted at the beginning of this paper, a progressive youth of NU amazed and murmured, "What sign is this?"

\section{The Encounter between Islamists and Traditional Islam: A Theoretical Reflection}

By looking at this phenomenon, we need to re-question the segregation of radical Islam and moderate Islam. Nowadays, radical Islam and moderate Islam are deemed as two separate entities. Integrating both is assumed to be impossible. Assumption like this is denying the sociological fact that the two groups live in the same social environment that can lead them to establish contact which influence each other. At least, the connectedness of the two groups could be caused by two things: a conservative attitude of the two groups in treating political and social situation in which they live.

Conservative character of traditional Islam can be seen from the figures or sometimes also referred to as the traditional Islamic scholars. The kyai is known for a very high commitment to the heritage of classical Islamic scholarship which was formulated by the scholars in the formative era of Islamic sciences. With moral and scientific

\footnotetext{
30 Interview with M. Wahid, the Branch Chairman of IPNU Bangkalan, period 20092011, March $5^{\text {th }}, 2011$.
} 
qualifications they have, these scholars become the axis for the understanding of Islam and the movement among traditional Islam.

These scholars were educated Muslims from the traditional Islamic educational institutions, which in Indonesia is often referred to as pesantren. They are experts in the field of classical Islamic sciences. Therefore, they assume themselves as the most authoritative one to speak on behalf of Islam. One of the characteristics of the scholars is a very strong determination to preserve the legacy of the classical Islamic scholarship. ${ }^{31}$

Muhammad Qasim Zaman exemplifies the scholar's attitude of this kind to the case of a Muslim scholar in Pakistan, Mawlana Muhammad Taqi 'Uthmani. He asserts that the meaning of jibad includes aggression against non-Muslim nations. This answer is likely to be the radical understanding of Islam among Muslims. But, this assumption is completely wrong because these scholars only want to preserve the meaning of jihad as embodied in the books of classical Islamic heritage of great scholars of Islam in the past. ${ }^{32}$

Here, it can be said that the traditional Muslim scholar is a conservative in terms of doctrine. However, he is not radical in the sense of radical Islamism because he did not commit any violence in his movement.

On the other hand, Islamists are people or groups who treat Islam as an ideology of social and political movement. Some of them are educated from modern educational institutions, not from Islamic institutions. They have a strong commitment to implement Islamic law literally. For this group, Islam is believed to have provided technical guidelines for all aspects of life. Islamic commitment and literal understanding of the doctrine of Islam bring them into Muslim religiopolitical activists who seek to build a society and an Islamic state in the modern era according to what the Prophet practiced in the past. The group is also called fundamentalist, revivalist, or radical Islamist, in which the latter is loaded with nuance of violence.

In many cases, the relationship between Islamists and Muslim traditionalists is complex and contradictory. The Islamists accuse traditional Muslim scholars as the people who do not know the

31 Muhammad Qasim Zaman, "Pluralism, Democracy, and the Ulama," in Robert W. Hefner (ed.), Remaking Muslim Politics: Pluralism, Contestation, Democaratization (Princeton and Oxford: Princeton University Press, 2005), p. 69.

32 Ibid., pp. 68-69. 
problems of modern life. Knowledge of the classical scholars is deemed having no connection with the problems of society and is unable to resolve the problems of the people. On the other hand, the traditional Muslim scholars accuse the Islamists as not qualified to interpret Islamic teachings so that they are not qualified to speak on behalf of Islam.

Activism, in socio-political issues, is a substance to distinguish between the Muslim scholars and the Islamists. The Islamists tend to be an activist who attempt to implement Islamic law as it is spelled out in the classical Islamic books. Whereas, Muslim scholars just treat it as a classical Islamic heritage that must be preserved. This attitude is frequently called as "theoretical defense."

Even so, there is a chance where the two groups come closer and work together. As mentioned above, both Muslim scholars and Islamists are essentially conservative. Both put liberal Muslims as their common enemy. The presence of liberal Islamic movement is considered endangering the basic principles of Islam. No wonder if one of the issues that unites conservative from the two groups is the limit of human's reason in understanding Islam. According to Muslim scholars and Islamists, the human's reason is only allowed to operate outside of what has been revealed by God. "And on this, the Islamists and 'ulamà' are in complete agreement," said Zaman. ${ }^{33}$

Not surprisingly, if a youth of NU sees Islam in the perspective of rational approach based on modern values it will contrast to those of NU's older generations. This is what we can see in Aliman Harish's figure, a youth of NU graduated from IAIN (State Institute for Islamic Studies) and was the former activist of PMII Surabaya, and he is now active in a Non-Governmental Organization (NGO) in the framework of strengthening democracy in society.

He could not accept the fact that NU could be hand in hand with the FPI. He also could not accept the state intervention in the religious affairs of the people, an attitude which is clearly in contrast to NU. This attitude seems to be at odds with the strong endorsement of NU towards the FPI in Bangkalan. The argument used in looking at the issues of function of the state and religious freedom is also very different from those used by the NU's management.

33 Muhammad Qasim Zaman, The Ulama in Contemporary Islam: Custodians of Change (Princeton and Oxford: Princeton University Press, 2002), p. 172. 
I also wonder why the kyais in Madura are so close to FPI, so I guess that it is a must or for granted since the elderly kyais here learn from the classical books of the classical Muslim scholars in which they also teach what is championed by the FPI. The kyais in Madura are childish. I truly do not agree with the violent ways as practiced because our country is based on constitution. No right for everyone to judge someone who is considered to be different from his. In East Java, in general, the government or the Governor, Soekarwo, shows that they are in a depressed position and lose from the violent groups. As the publication of Governor's regulation (East Java Governor Decree on the prohibition of the Abmadiyya's activities in East Java), I think that this is precisely the government's attempt to legalize violence. I do not agree with the violent methods used by the FPI as a whole because our country is a constitutional state and does not justify any violence in the name of anything. It is only because Ahamadiyah is considered a misguided sect then its followers are not allowed to live in Indonesia? MUI's fatwa (legal opinion) said that Governor Decree was forgetting the other sides, such as brotherhood and so on... ${ }^{34}$

Thus, conservatism is what makes the traditional 'ulamā' (Muslim scholars) and Islamists unite and fight against liberal Muslims who are considered endangering Islam. Without realizing it, the excessive exposure of Islamic thought developed by liberal Islam has an impact on the fusion of the Islamists and the traditional Muslim scholars. Merging the two would generate thought and Islamic movement to be complementary to each other. The Islamists will gain theological legitimacy of the Muslim scholars, on the contrary the, Muslim scholars will support the Islamists' ideas.

The unity of both bring the Muslim scholars begin to enter the modern issues that have been the concentration among the Islamists, such as the resistance to Western values, secular rationalism that are deemed hostile to Islamic norms, the implementation of shari'ah as a positive law, and so on. They oppose the promises offered by secular ideologies, such as liberalism, nationalism and socialism which are considered just nonsense. They perceive liberal Muslims as an agent of

\footnotetext{
34 Interview with Aliman Harish, the Branch Chairman of ANSOR Bangkalan and Director of Leksdam (Board of Social Studies and Democracy), March 4 2011.
} 
all these secular ideologies. They also struggled to start Islamizing the country by offering shari'ah as the solution to all problems inflicting the nation. ${ }^{35}$

The weakness of legitimacy and political control of the government is another factor that encourages Muslim scholars ('ulamā') to be more active in politics. Green's studies on attitudes and political behavior of the Muslim scholars in Tunisia concluded that one of the important variables that determined political behavior of the Muslim scholars was the government's control. If the government has effective and strong control over society, Muslim scholars will tend to be passive. On the contrary, if the government does not have effective control, the leadership of the society will be taken over by scholars. ${ }^{36}$ Thus, the involvement of scholars into practical politics depends on the strength or weakness of government's control and legitimacy over the society.

The fusion between the Muslim scholars and Islamists in Pakistan and Indonesia confirms such a matter. After Pakistan was formed, the government was still unstable. The first issue that arose was the place of Islam in Pakistan and non-Muslims status. Secular and liberal Muslims preferred to make Pakistan a secular state by making the UK as a model, while the Muslim scholars and Islamists wanted Islam as the ideology of state. Traditional 'ulam $\bar{a}$ ' and Islamists wanted a theocracy, in which the state of Pakistan should be run based on the principles of Islam as political theory of Islam as set out in the classical works. ${ }^{37}$

In Indonesia, the convergence between traditional Muslims and Islamists occurred in two periods. The first period was after its independence when the traditional Muslim scholars were working with Masyumi to make Islam as the ideology of the state. The second period was after the fall of Soeharto. Making Indonesia comes closer to Islam is one of the issues offered by the traditional Muslims and Islamists on

\footnotetext{
35 Zaman, The Ulama in Contemporary Islam, pp. 171-172.

36 Arnold H. Green, "Political Attitudes and Activities of the Ulama in the Liberal Age: Tunisia as an Exceptional Case," in Abubaker A. Bagader (ed.), The Ulama in the Modern Muslim Nation-State (Kuala Lumpur: Muslim Youth Movement of Malaysia, 1983), p. 172.

37 Ahmad Aziz, Islamic Modernism in India and Pakistan 1857-1964 (London, Bombay, Karachi: Oxford University Press, 1967), pp. 238-241.
} 
the grounds that the secular Indonesia has failed to provide the public goods for its people.

In both cases, government's control and legitimacy are weak since they were being in their transition period. This situation provides an opportunity for Muslim scholars entering the field of practical politics as a form of the sense of responsibility to guide the people. And when the kyais entered into the arena of practical politics, they have been hailed by the Islamists. Consequently, these two groups fuse with the mutual doctrine and movement reinforcing to one another.

\section{Radicalization-De-radicalization: The Price of an Encounter}

As stated before, the encounter between moderate Islam and radical Islam is possible because of the same view. Both make classical Islamic discourse as an Islamic ideal to be realized at this time if we want to build an ideal Muslim society. It is merely the ideal classical Islam which was originally a moral appeal among the traditional 'ulama', that could turn into a blue print in political movements. The traditional 'ulama' that were apolitical turned to be active politically by performing missionary movements that used political instruments.

The changes in this movement occur when two prerequisites are met. First, the specific political situation in which traditional Islamic force has been able to control the political posts. Second, there is an encounter with Islamic force which is able to articulate Islamic ideals in terms of classical and modern political movements.

In Bangkalan, the two prerequisites are fulfilled. Currently, both legislative and executive bodies are controlled by politicians from NU. Meanwhile, FPI has entered into Bangkalan and has closely linked since the beginning, even indistinguishable, with NU. Both have brought traditional 'ulama' shifting their preaching activity from a politically inactive moral appeal to a more political missionary movement.

This phenomenon actually represents the mainstream Islamic political view that sees Islam as din (religion) and dawlah (state). Political view that puts Islam as a primary reference is not able to avoid separating between Muslim citizens and non-Muslim citizens, where the latter is treated as the second class. This principle is diametrically in contrast with the principles of democratic governance, in which all citizens have the same status and are treated equally. Law is built on 
the common grounds, and is not based on arguments of religious belief. ${ }^{38}$

The principle of democracy is seen as an instance of secularism which is strongly opposed by both traditional Muslims and radical Islamists. On the other hand, the liberal Muslims view that the state should be managed according to the principles of modern democracy because it is only by democracy any form of discrimination can be avoided. Liberal Muslims also try to interpret Islam on the perspective of human rights. Likewise, they maintain that freedom of religion is the most fundamental right that must be recognized, including here is the right to convert, a view that is not accepted by the traditional and the radical Muslims alike who base their understanding on the formulation of the classical Islamic jurisprudence that applies capital punishment for those who leave Islam.

If the traditional 'ulam $\bar{a}$ ' can still meet with radical Islamic groups as bounded by the same Islamic and political views, so that between the traditional 'ulama' and liberal Muslim scholars do not have any association except for the spirit of nonviolence. This is what we see today when the radical Islamic forces advanced, Islamic movements that promote democracy and human rights find themselves a minority. When the radical Muslims have joined with the traditional Muslims, they have turned into a majority Muslim force. Under these circumstances, it is no longer relevant to assume that radical Islam is a minority.

On the other hand, the attitude of the view that the relationship between radical Islam and moderate Islam is a unidirectional relationship in which the latter merely simplifies the complexity of the

\footnotetext{
38 Masdar Hilmy discussed the problem of the relationship between political theory of Islam and democracy by dividing it into three categories: Huwaydian (a concept developed by Fahmi Huwaydi, who put Islam as compatible with democratic principles), Mawdudian (a concept developed by Mawdudi, who accepted democracy, but put Islam as the main reference), and Qutbian (a concept developed by Sayyid Qutb, who completely rejected the concept of democracy as it was considered as contrary to Islamic infidels). See Masdar Hilmy, "Muslims' Approaches to Democracy: Islam and Democracy in Contemporary Indonesia," Journal of Indonesian Islam, vol. 01, no.01 (June 2007), pp. 56-68; the same problem was also discussed by Bahtiar Effendy. He divided it into two groups: textual approaches to Islam which regard democracy as incompatible with Islam, and substantial approach that sees Islam and Muslims based on a basic concept in accordance with the principles of modern democracy. Bahtiar Effendy, Islam and the State in Indonesia (Singapore: ISEAS, 2003), chapter I.
} 
object appears to be the case. The opposite view does not give any help in explaining this phenomenon. It is simply questionable to assume that since the moderate Islam is the majority, the closeness between the two would make the radical Islam idle.

Every meeting of two similar groups will always bear a mutual relationship and mutual influence. The greatness of NU has no significant value in the encounter among FPI's, NU's, and the pesantren's leaders in Bangkalan. This encounter is more determined by the bargaining power of each character that occurs not because of a formal collaboration among NU, FPI, and pesantren. Moreover, the reality also shows that most of the NU members are passive and silent majority, while the FPI members are very active. As a result, to consider that NU will dominate the encounter with FPI should be questioned seriously.

In the context of this meeting, it is clear that FPI leaders cannot be underestimated, both in terms of their knowledge of Islam and their insights on the existing socio-political situation. Figures gathered in Bangkalan could be said to have the same degree of scientific qualifications. On the other hands, Rizieq Shihab's capability in the field of classical Islamic scholarship represents a pride among the traditional Muslims that cannot be ignored.

Rizieq Shihab is clearly less charismatic than Fahrillah Aschal in the eyes of Bangkalan Muslims. Precisely because of Fahrillah Aschal's charisma, so that Rizieq approaches him to establish FPI in Bangkalan. Nevertheless, Rizieq obviously has other advantages, namely network, experience in organizing movement, access to politicians and media. ${ }^{39}$ In this case, Rizieq will be able to put himself as a mentor in the movement.

\section{Conclusion}

By looking at various things, then the encounter between NU and FPI in Bangkalan will take effect in both directions. In less balanced degrees, NU becomes both the subject and object, so does FPI. NU

\footnotetext{
39 As previously predicted by Liddle, the scriptural Muslims would have huge political resources after the fall of Suharto. This prediction was based on the fact that they had access to the alliance and, in addition, were supported by politicians, media, and organizations. See R. William Liddle, "Skripturalisme Media Dakwab: Satu Bentuk Pemikiran dan Aksi Politik Islam Masa OrdeBaru," translated by Ahmad Sahal and Saiful Mujani, in R. William Liddle, Islam, Politik dan Modernisasi (Jakarta: Pustaka Sinar Harapan, 1997), p. 126.
} 
cannot completely change FPI into NU in other cloth. In contrast, FPI cannot freely push NU to apply its agendas.

For those who want NU remains moderate, they may be disappointed. The reality shows that the inclusion of FPI into NU's community brings about increased radicalization within NU. As data has suggested, since the existence of FPI in Bangkalan, there have been several sweepings on illicit places. The flag used is FPI, but mostly the perpetrators are kyais with their students.

On the other hand, for those who want NU shifts to be as radical as FPI, so that there will be no difference between both of them, they will also be disappointed. Since the beginning, Fahrillah stated that he would hold FPI in Bangkalan precisely to reduce the potential of violence and would not allow it to be face-to-face with $\mathrm{NU}$ and pesantren. Despite several time sweepings, the FPI's movement was away from radical, if its radicalism is measured and identified with violence, as FPI has done so far elsewhere.

What can be stated here is that the proximity of FPI and NU in Bangkalan bears de-radicalization and radicalization. The deradicalization happens in the body of FPI when compared to the FPI's basic character as radical Islam to act violence everywhere. Meanwhile, radicalization occurs in the body of NU when compared to the NU's basic character as a moderate Islamic organization which is away from violence in preaching Islam. Perhaps, this is the price to be paid in every encounter. []

\section{References}

\section{Books and Articles}

Anam, Choirul. Pertumbuban dan Perkembangan NU. Surabaya: Duta Aksara Mulia, 2010.

Aziz, Ahmad. Islamic Modernism in India and Pakistan 1857-1964. London, Bombay, Karachi: Oxford University Press, 1967.

Binder, Leonard. Islam Liberal: Kritik Terbadap Ideologi-Ideologi Pembangunan. Translated by Imam Muttaqin. Yogyakarta: Pustaka Pelajar, 2001.

Bubalo, Anthony and Greg Fealy. Joining the Caravan? The Middle East, Islamism and Indonesia. Alexandria: Lowy Institute for International Policy, 2005. 
Effendy, Bahtiar. Islam and the State in Indonesia. Singapore: ISEAS, 2003.

El Fadl, Khaled Abou. Cita dan Fakta Toleransi Islam: Puritanisme versus Pluralisme. Translated by Heru Prasetia. Bandung: Arasy, 2003.

Fealy, Greg and Virginia Hooker (eds).Voices of Islam in Southeast Asia: A Contemporary Sourcebook. Singapore: ISEAS, 2006.

Green, Arnold H. "Political Attitudes and Activities of the Ulama in the Liberal Age: Tunisia as an Exceptional Case." in Abubaker A. Bagader (ed.). The Ulama in the Modern Muslim Nation-State. Kuala Lumpur: Muslim Youth Movement of Malaysia, 1983.

Hamim, Thoha. Islam \& NU di Bawah Tekanan Problematika Kontemporer. Surabaya: Diantama, 2004.

Hefner, Robert W. "Muslim Democrats and Islamist Violence in PostSoeharto Indonesia," in Robert W. Hefner (ed.). Remaking Muslim Politics: Pluralism, Contestation, Democratization. Princeton, New Jersey: Princeton University Press, 2005.

Hilmy, Masdar. "Muslims' Approaches to Democracy: Islam and Democracy in Contemporary Indonesia." Journal of Indonesian Islam. vol. 01. no. 01 (Juni 2007).

Hooker, Virginia. "Developing Islamic Arguments for Changing Through "Liberal Islam," in Virginia Hooker and Amin Saikal (eds). Islamic Perspectives on the New Millenium. Singapore: ISEAS, 2004).

Ida, Laode. NU Muda: Kaum Progresif dan Sekularisme Baru. Jakarta: Erlangga, 2004.

Jamhari and Jajang Jahroni (eds). Gerakan Salafi Radikal di Indonesia. Jakarta: PT Raja GrafindoPersada, 2004.

Koentjaraningrat. Pengantar Ilmu Antropologi. Jakarta: Rineka Cipta, 2009.

Khuluq, Lathiful. "K.H. Hasyim Asy'ari: Profil Pejuang dari Jombang." In Jajat Burhanudin \& Ahmad Baedowi (eds). Transformasi Otoritas Keagamaan: Pengalaman Islam Indonesia. Jakarta: Gramedia, 2003.

Liddle, R. William. "Skripturalisme Media Dakwah: Satu Bentuk Pemikiran dan Aksi Politik Islam Masa Orde Baru." Translated 
by Ahmad Sahal and Saiful Mujani. In R. William Liddle. Islam, Politik dan Modernisasi. Jakarta: Pustaka Sinar Harapan, 1997.

Mulyono, Mohammad Tikno. Dakwah Front Pembela Islam (FPI) di Kabupaten Bangkalan (Studi Kualitatif tentang Gerakan Amar Ma'ruf Nabi Munkar). Unpublished thesis, Dakwah Faculty IAIN Sunan Ampel Surabaya, 2009.

Murphy, Caryle. Passion for Islam: Shaping the Modern Middle East: The Egyptian Experiance. New York: Scribner, 2002.

Othman, Norani (ed.). Muslim Women and The Challenge of Islamic Extremism. Selangor: Sister in Islam,2005.

Rahmat, M. Imdadun. Arus Baru Islam Radikal: Transmisi Revivalisme Islam Timur Tengah ke Indonesia. Jakarta: Erlangga, 2005.

Rumadi. Post Tradisionalisme Islam: Wacana Intelektualisme dalam Komunitas NU. Jakarta: DEPAG RI, 2007.

Said, Edward. Orientalim. New York: Vintage, 1979.

Schwartz, Stephen Sulaiman. Dua Wajab Islam: Moderatisme vs Fundamentalisme dalam Wacana Global. Translated by Hodri Ariev. Jakarta: Libforall, Blantika, The Wahid Institute, Center for Islamic Pluralism, 2007.

Wahid, Abdurrahman (ed.). Ilusi Negara Islam: Ekspansi Gerakan Islam Transnasional di Indonesia. Jakarta: The Wahid Institute, Gerakan Bhinneka Tunggal Ika, Maarif Institute, 2009.

Weismann, Itzchak. "Sa'id Hawwa: The Making of Radical Muslim Thinker in Modern Syria." In Syafiq Mughni (ed.). An Anthology of Contemporary Middle Eastern History. Montreal: IndonesiaCanada Islamic Higher Education Project, n.d.

Wiyata, A. Latief. Carok Konflik Kekerasan dan Harga Diri Orang Madura. Yogyakarta: LKiS, 2006.

Zaman, Muhammad Qasim. "Pluralism, Democracy, and the Ulama." in Robert W. Hefner (ed.). Remaking Muslim Politics: Pluralism, Contestation, Democaratization. Princeton and Oxford: Princeton University Press, 2005.

--------. The Ulama in Contemporary Islam: Custodians of Change. Princeton and Oxford: Princeton University Press, 2002. 


\section{Online Sources}

http://www.tempointeraktif.com

http://www.nasional.vivanews.com

bahtsulmasail-nu@yahoogroups.com

http://www.bangkalankab.go.id

http://www.nuonline.com

http://www.seputarjatim.com 